\title{
The influence of the opponent's quality on team offensive efficacy in youth football: an observational study with sequential analysis \\ La influencia de la calidad del oponente en la eficacia ofensiva del equipo en el fútbol juvenil: un estudio observacional con análisis secuencial \\ *Matheus de Oliveira Jaime, *Leandro Rechenchosky, *Vanessa Menezes Menegassi, **Paulo Henrique Borges, ***João Cláudio Braga Pereira Machado, *Wilson Rinaldi \\ *Universidade Estadual de Maringá (Brasil), **Universidade Federal de Santa Catarina (Brasil), ***Universidade Federal do Amazonas (Brasil)
}

\begin{abstract}
The aim of this study was to investigate the influence of the opponent's quality on teams' offensive efficacy of a Brazilian youth football team. The sample comprised 1.304 offensive sequences, from a U-17 team of the Paraná championship. The offensive sequences were divided according to the opponent's quality («high quality», «intermediate quality» and «low quality»).Team's offensive patterns were analysed through Lag Sequential Analysis. Thus, SoccerEye and SDIS-GSEQ software's were used ( $p d » .05 ; z e » 1.96)$. Offensive patterns with efficacy occurred mainly from directly ball recoveries (lag-5: $\mathrm{z}=3.13$; lag $-3: \mathrm{z}=2.93$ ), with progression through ball conduction (lag $-4: \mathrm{z}=2.85 ; \operatorname{lag}-3: \mathrm{z}=2.40 ; \operatorname{lag}-2: \mathrm{z}=2.64$ ) and dribble (lag $-5: 2.62$; $\operatorname{lag}-2: \mathrm{z}=2.51 ; \operatorname{lag}-1: \mathrm{z}=2.13 ; 1.97)$, playing between the lines against the opponent's last defenders' line (lag $-1: \mathrm{z}=3.42 ; 2.72 ; 2.05 ; \operatorname{lag} 0: \mathrm{z}=4.65$; $5.06 ; 3.15 ; 3.02)$ or performing rupture unmarks for the empty space between the goalkeeper and the last defensive line (lag $-4: \mathrm{z}=3.11 ; \operatorname{lag}-1: \mathrm{z}=3.48$; $\operatorname{lag} 0: \mathrm{z}=4.13 ; 7.80)$. Pressed numerical equality in game centre at defensive zones stimulated the possession loss $(\operatorname{lag}-2: \mathrm{z}=2.06 ; \operatorname{lag}-1: \mathrm{z}=3.01 ; \operatorname{lag} 0$ : $\mathrm{z}=3.41 ; 1.96$ ), demonstrating the importance of the numerical and spatial relationship for the effectiveness of actions. The opponent's quality generated some oscillations in the patterns, nonetheless, in most patterns this team maintained similar behaviours. Considering this youth team, it is suggested that players be encouraged, regardless of the opponent's quality, to advance quickly from the defensive field; dominates the spaces between the lines; perform dribble, ball conduction and rupture unmarks towards the space between the goalkeeper and the opponent's last defensive line; in addition to pressing the opponent into their own field.
\end{abstract}

Keywords:Youth Sports. Offensive patterns. Game analysis. Sequential analysis. Opponent's quality.

Resumen: El objetivo de este estudio fue investigar la influencia de la calidad del oponente en la eficacia ofensiva de un equipo de fútbol Juvenil de Brasil. Se analizaron 1.304 secuencias ofensivas, extraído de 17 partidos de este equipo en el Campeonato Sub-17 de Paraná, 2019. Las secuencias ofensivas se dividieron según la calidad del oponente («alta calidad», «calidad intermedia» $\mathrm{y}$ «baja calidad»). Los patrones ofensivos del equipo se analizaron a través del análisis secuencial de retardos. Por lo tanto, se utilizaron los softwares SoccerEye y SDIS-GSEQ (pd».05; ze»1.96). Los patrones ofensivos con eficacia ocurrieron principalmente a partir de recuperaciones directas de balón (lag -5: $\mathrm{z}=3.13 ; \operatorname{lag}-3: \mathrm{z}=2.93$ ), con progresión a través de conducción (lag -4: $\mathrm{z}=2.85 ; \operatorname{lag}-3: \mathrm{z}=2.40 ; \operatorname{lag}-2: \mathrm{z}=2.64)$ y gambeta $(\operatorname{lag}-5: 2.62 ; \operatorname{lag}-2: \mathrm{z}=2.51 ; \operatorname{lgg}-1: \mathrm{z}=2.13 ; 1.97)$, jugando entre líneas contra la última línea de defensores del oponente $(\operatorname{lag}-1: \mathrm{z}=3.42 ; 2.72 ; 2.05 ; \operatorname{lgg} 0: \mathrm{z}=4.65 ; 5.06 ; 3.15 ; 3.02)$ orealizando desmarques de ruptura para el espacio vacío entre el portero y la última línea de defensa ( $\operatorname{lag}-4: \mathrm{z}=3.11 ; \operatorname{lag}-1: \mathrm{z}=3.48 ; \operatorname{lag} 0: \mathrm{z}=4.13 ; 7.80)$. Laigualdad numérica presionada en el centro de juego en las zonas defensivas estimuló la pérdida de posesión (lag $-2: \mathrm{z}=2.06$; lag $-1: \mathrm{z}=3.01 ; \operatorname{lag} 0: \mathrm{z}=3.41 ; 1.96$ ), demostrando la importancia de la relación numérica y espacial para la efectividad de las acciones. La calidad del oponente generó algunas oscilaciones en los patrones, sin embargo, en la mayoría de los patrones este equipo mantuvo comportamientos similares. Teniendo en cuenta este equipo juvenil, se sugiere que se aliente a los jugadores, independientemente de la calidad del oponente, a avanzar rápidamente desde el campo defensivo; dominar los espacios entre líneas; realizar gambeta, conducción y desmarques de ruptura hacia el espacio entre el portero y la última línea defensiva del adversario; además de presionar al oponente en su propio campo.

Palabras clave: Deportes juveniles. Patrones ofensivos. Análisis de juego.Análisis secuencial. Calidad del oponente.

\section{Introduction}

Football is a team sport in which players need to interact with their teammates to manage spatio-temporal constraints imposed by confrontation (Barreira, Garganta, Guimarães, Machado \& Anguera, 2014). These actions are developed in a common, complex and unpredictable space, where all actions are interrelated. Due to this chaotic and complex environment, it is recommended that the players and teams are guided

Fecha recepción: 10-05-21. Fecha de aceptación: 06-10-21

Matheus de Oliveira Jaime

matheus.o.jaime@gmail.com by a general guiding order (strategic component), but that they also know how to perceive the information of the environment to manage the game space and adopt flexible actions in response to the unpredictability of game situations (tactical component) (Gréhaigne \& Godbout, 1995).

The tactical component concerns the actions performed voluntarily by the players during the complex game system, in order to adapt to the immediate demands of the opposition and dynamic environment (Duarte, Araújo, Folgado, Esteves, Marques \& Davids, 2013; Hewitt, Greenham \& Norton, 2016). Considering this tactical prominence, it is important to investigate patterns of tactical actions when players are in 
competitive contexts, as this research could provide important information to optimize the training process and strategic planning. The aforementioned action patterns are defined as non-occasional products of organisms' interactions with the environment (Sarmento, 2012).

A considerable part of the studies on tactical actions have adopted the evaluation of the players' performance based on unilateral criteria, which may neglect the interaction of different parameters that cooperate for the manifestation of tactical qualities (Folgado, Bravo, Pereira \& Sampaio, 2018). In order to fill part of this gap, recent studies with multilateral perspectives aimed to understand the effects of contextual aspects, such as match location (Caballero, García-Rubio \& Ibáñez, 2017; Pic \& Castellano, 2017), quality of the opponent (Caballero, García-Rubio \& Ibáñez, 2017; Gómez, Mitrotasios, Armatas \& Lago-Peñas, 2018; Errekagorri, Castellano \& Echeazarra, 2020), competitive level (Borges et al., 2019), and match status (Machado, Barreira \& Garganta, 2014; Praça, Lima, Bredt, Sousa, Clemente \& Andrade, 2019) on tactical actions by players and teams.

As observed, the quality of the opponent is suggested to be a contextual variable that can significantly affect performance (Caballero, García-Rubio \& Ibáñez, 2017). For example, research highlights those elite professional players, when confronting teams of inferior quality, tend to offensively occupy larger areas in width and depth (Castellano, Álvarez, Figueira, Coutinho \& Sampaio, 2013), in addition to having a greater relative probability of scoring the goal at each shot, regardless of the effect of opposing pressure and the numerical relationship in the centre of the game (Gonzalez-Rodenas, Mitrotasios, Aranda \& Armatas, 2020). Meanwhile, when facing highlevel opponents, it is more difficult for teams to find and create spaces, as the opponents increase the density and pressure in the centre of the game, increasing the complexity of decision making (Barreira, Garganta, Castellano, Machado \& Anguera, 2015).

Despite the good consistency found in the literature in studies with tactical actions by elite professional players from the main national leagues (Castellano et al., 2013; Gómez et al., 2018) and world championships (Machado, Barreira \& Garganta, 2014; Barreira et al., 2015), an incipience was noted in studies that addressed to investigate how the performance of youth teams and players is affected by situational aspects, such as the opponents' quality.

Regarding the relationship between effectiveness and the influence of the context, youth football players are expected to present consistent actions throughout the matches to comply with the game ideas. However, considering that less specific knowledge of the modality (Williams, Davids \& Williams, 2000; Costa, Garganta, Fonseca \& Botelho, 2002) can lead to behavioural inconsistency in the face of varied contextual situations - as is the case when facing teams of high, intermediate and low quality and that in order to achieve an accurate state of consistency, good prior capture and processing of environmental information are required, which significantly improves the efficiency of the execution of tactical actions (Wilson, Wood \& Vine, 2009; Gonçalves, Noce, Barbosa, Figueiredo, Hackfort \& Teoldo, 2017). Increases in specific knowledge can only be conquered and improved with time and quality of practical experiences accumulated in the modality.

Considering the inconsistency found in the influence of opponents' quality on youth teams' performance, some questions were raised, such as: are the patterns of actions found in sequences with positive (with efficacy) and negative outcomes (without efficacy) different? Do these sequential patterns of tactical actions vary depending on the opponents' quality? Thus, the present study aimed to investigate the influence of the opponent's quality on the offensive effectiveness of a Brazilian youth team. Understanding the influence of these constraints may assist the technical staff to prepare and train youth football players and teams who know how to handle and manage these contextual situations of the game. It was hypothesised that the quality of the opponent influences the type of construction and the effectiveness of the offensive actions.

\section{Materials and methods}

This is a longitudinal, descriptive and observational case study. According to Chaverra, Gaviria \& González (2019), case study might be considered as a fundamental strategy for the scientific development and it allow us to understand people's behaviours in training and sporting events, recognizing interactions between teammates and opponent's etc. The observational methodology was used because it is considered a sensitive technique for capturing information from spontaneous sports actions in a natural environment (Anguera, Camerino, Castañer, Sánchez-Algarra \& Onwuegzbuzie, 2017).

\section{Participants}

Young Brazilian players (under-17) from a high-per- 
formance team in dispute for the first Paraná Championship division, season 2019, participated in this study. This team trains five times a week and quotes with selected players in several cities in Brazil. The sample was composed of 1,304 offensive sequences (29,228 events) extracted from 17 matches (10 away and 7 home matches). The inclusion criterion was: offensive sequences with at least three consecutive touches on the ball, and the exclusion criteria was: matches in which at least one of the teams was playing with 10 players or less for a more than $10 \%$ of the total time. The championship consists of 20 matches, nonetheless, 3 matches were excluded for meeting the exclusion criteria. Non-observation periods, due to technological and climatic reasons, did not exceed 10\% of the total observation time.

To reinforce the characterization of the team in question, it is highlighted that in 19 of the 20 matches of the season, the team adopted the 1-4-3-3 tactical shape, with a goalkeeper, two defenders, two full-backs, a defensive midfielder, two midfielders, two wingers and a centre-forward; while in just one match the 1-3-5-2 tactical shape was adopted. According to the team assistant coach, the team's game ideas and principles have not changed throughout the season. All training sessions were aimed at strengthening a game proposal based on: pressing zone marking in medium-high and high blocks and zonal marking in medium-low and low blocks; at the offensive phase, the team opted for build from behind in the first construct stage and quick acceleration to gaps in the subsequent phase, especially with short passes until reaching the finishing zone; the transition moments (offensive and defensive) sought to be aggressive and quick to recovery the ball or to attack the opponent's goal with few touches.

The football director, responsible for the club's youth category and for the athletes, was informed about the procedures that would be adopted and signed an authorization term prior to the study execution. This study was approved by the ethics committee of the State University of Maringá (Proc. 1,627,516).

\section{Taxonomic system}

Considering the specific taxonomy of the area, the study is classified as ideographic (an observed unit), with dynamic temporality (follow-up) and heterogeneity of possibilities (multidimensional) (Anguera, BlancoVillaseñor, Hernández-Mendo \& Losada, 2011). The study considered the checklist for studies based on observational methodology, suggested by ChacónMoscoso et al. (2019).

\section{Procedures}

To record the matches a Kodak Pixpro Az501 (16 megapixel) digital camera was positioned on a plane higher than the playing field, in order to capture the entire length of the field and facilitate viewing of the actions resulting from the match. The games were analysed using the SoccerEye observation system, version 3.1.0.5 (Barreira, Garganta, Prudente \& Anguera, 2012; Barreira et al., 2014) (Table 1). SoccerEye evaluates the offensive phase by recording 80 possible and mutually

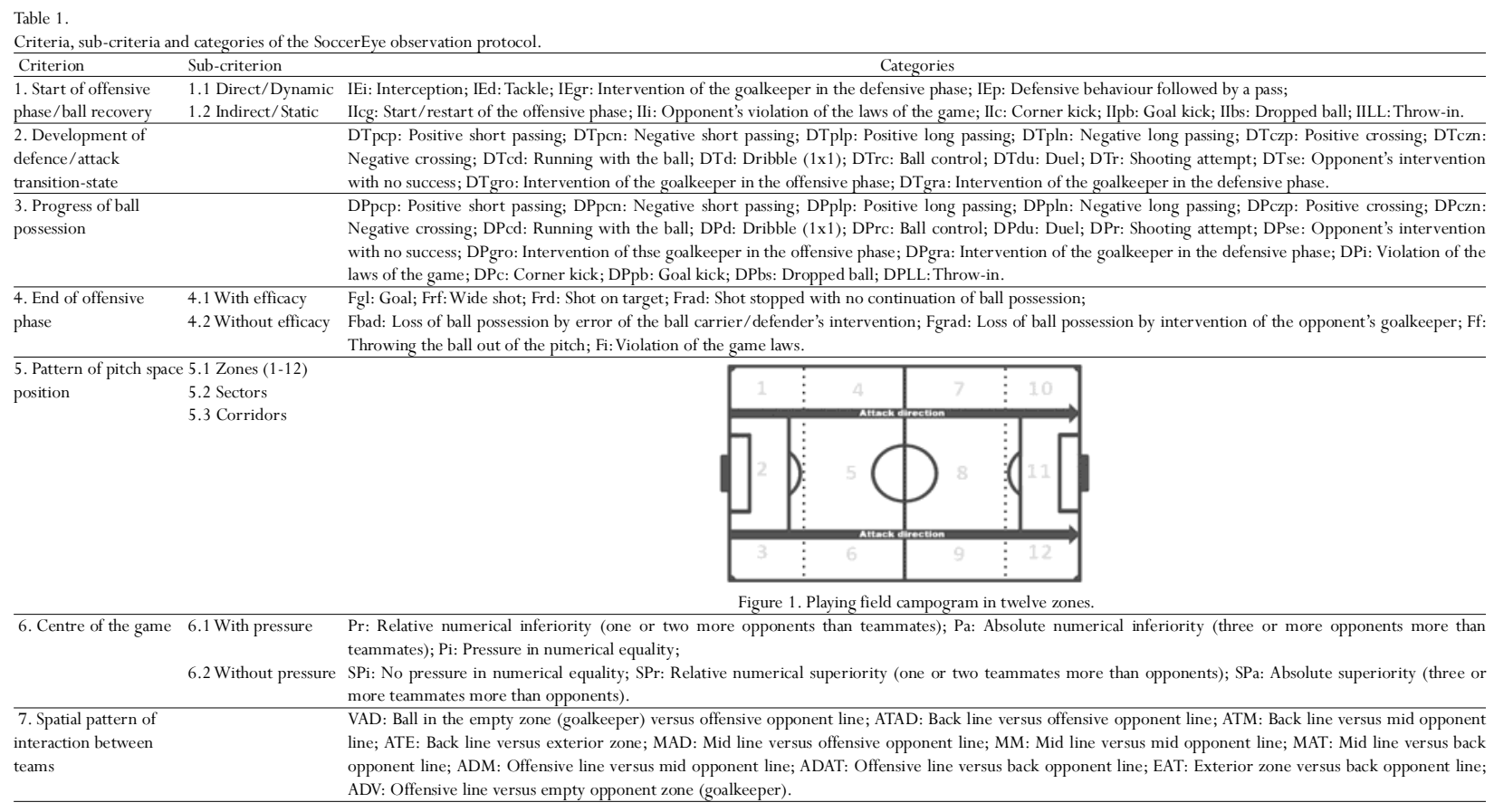


exclusive variables, belonging to 7 analysis criteria (Table 1). After recording the observations, a report in the form of a spreadsheet, without separation by columns,

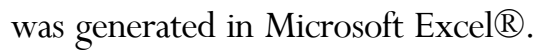

The opponent's quality variable was considered to divide the offensive sequences into three distinct groups. The championship stage reached by each team (1st, 2nd and 3rd stage) and the final positioning were the determining factors chosen by the authors (Figure 2).

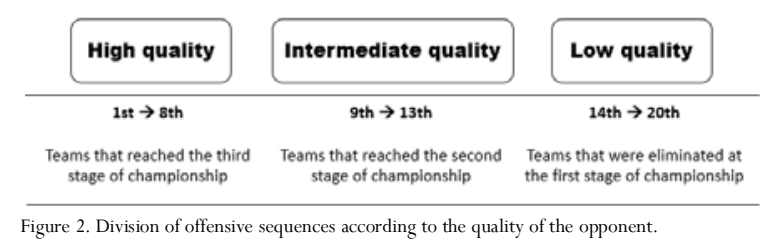

\section{Statistical analysis and reliability}

The data were analysed using SDIS-GSEQ (version 5.1) (Bakeman \& Quera, 2011). Sequential delay analysis (ASR) was used to investigate the existence of stability in the succession of events with probabilities greater than chance. ASR uses the chi-square calculation to reject the null hypothesis, with a significance of $p \mathrm{~d} \gg .05$ (Castelão, Garganta, Afonso \& Teoldo, 2015). The data were reported based on the association between the object conducts and the criterion conducts through the adjusted residue ( $z$-value); $z$ values greater than 1.96 ( $p \mathrm{~d} » .05)$ were considered significant. Criterion 4 (End of offensive phase) was adopted as conduct criterion, while the variables of the six (6) other criteria were adopted as object conduct. Similar to that found in other studies, delay five was adopted as the maximum delay and a retrospective analysis was applied (Castelão et al., 2015; Praça, Silva, Barreira, Garganta \& Greco, 2017); object conducts that presented significant values (ze»1.96) were classified as having a strong association with the outcome (conduct-criterion).

In order to provide control over the quality of the data, one of the researchers in the present study was trained (ad hoc) by an experienced analyst in the use of SoccerEye software. After a process of familiarization with the protocol (Table 1), the Spanish championship game - Barcelona vs Málaga (2015) -, previously analyzed by the instrument creators and suggested by the training instructor, was analysed and reliability was verified in five of the seven analysis criteria. Subsequently, some concepts that caused doubts in the first analysis were reviewed and a new intra-observer evaluation (testretest) was performed, which was considered reliable according to Cohen's Kappa index (Cohen, 1960) for all seven criteria (Table 1$): k=.92 ; .97 ; .98 ; .83 ; .95 ; .91$; .92; respectively.

With respect to inter-observer reliability, an independent analyst received training with the instrument under the supervision of the main researcher of this study. In a pilot study, 626 offensive sequences were analysed by the main evaluator and more than $10 \%$ (67 offensive sequences), indicated by the literature (Tabachnick \& Fidell, 2012), were re-analysed by the independent analyst. Initially, the results provided reliability for five of the seven analysis criteria. Thus, a resumption of the concepts was carried out among the analysts and a new evaluation was performed, which was considered reliable. For this sample, as mentioned above, the Cohen Kappa index was used, obtaining values greater than $k>.81$ for all seven criteria (Table 1 ): $k=.92 ; .89 ; .89 ; .87 ; .89 ; .88 ; .82$; respectively.

\section{Results}

The results of the investigation were listed according to the quality of the opponent, indicated by their position in the final classification of the championship (Figure 2). In the current study we included three analysis groups. The sequences with efficacy were those that ended in a shot but without a goal (Frd, Frf and Frad). On the other hand, ineffective sequences consisted of those that did not result in a shot (Fbad, Fgrad, Ff, and Fi). In these maps, the lines represent actions referring to the same criterion positioned in up to five delays (lags), while the columns correspond to actions referring to different criteria positioned in the same delay.

Patterns in effective offensive sequences, except goal (Frd, Frf and Frad)

Figure 3 shows the map of interactions between offensive actions with effectiveness (except goal) detected against opponents of high quality (I), intermediate quality (II) and low quality (III).

(I) Against high quality opponents, the team tended to initiate the offensive sequences with efficacy with interception actions (lag -5: $z=3.13$ ) or from a throwin (lag -3: $z=2.27$ ), already in advanced areas of the playing field. When the ball was recovered directly, the team tended to progress in transition through positive ball conduction (lag -3: $z=2.40$ ) and opted to dribble (lag -1: $z=2.13$ ) to penetrate the opponent area. The actions immediately prior to the shot were performed through positive crosses (lag $-1: z=5.51)$ and dribble (lag -1: $z=2.91$ ), exploring the right and central zone 


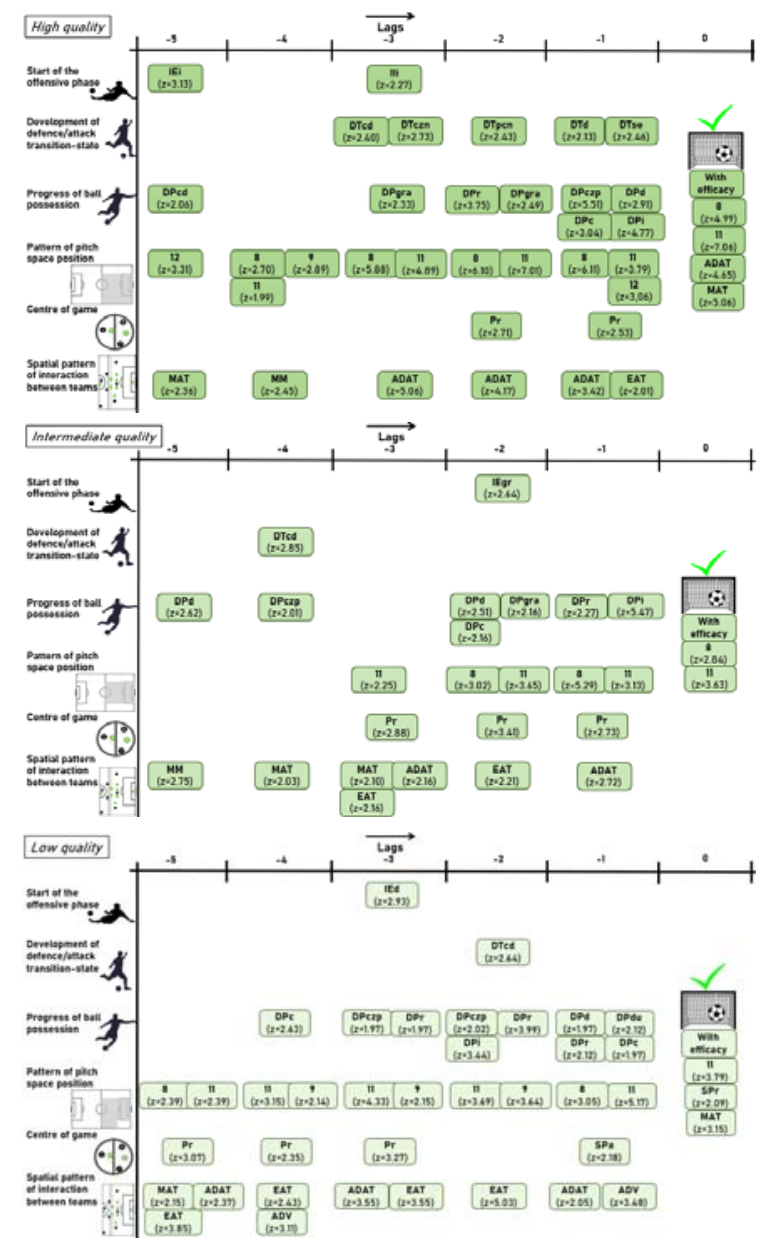

Figure 3. Map of interactions between offensive patterns with effectiveness against high (I) intermediate (II), and low quality opponents (III).

Note: IIi: Infringement of the opponent to the laws of the game; IEi: Interception; IEgr: Goalkeeper action in the defensive phase; IEd: Disarm; DTcd: Ball conduction; DTse Unsuccessful opponent's intervention; DTpcn: Short negative pass; DTczn: Negative crossing; DTd: Dribble (1x1); DPi: Opponent's violation of the laws of the game; DPd: Dribble (1x1); DTd: Dribble (1x1); DPi: Opponent's violation of the laws of the game; DPd: Dribble
DPc: Corner kick; DPr: Finalization; DPczp: Positive crossing; DPcd: Running with the ball, DPgra: Team goalkeeper action in the defensive phase; DPdu: Duel; Pr: Relative inferiority; SPr: Relative superiority; SPa: Absolute superiority; ADAT: Early line vs. delayed line; ADV: Line ahead $\mathbf{x}$ goalkeeper of the opposing team; MAT: Midline $\mathbf{x}$ delayed line; MM: Midline $\mathbf{x}$ Midline; EAT: Outer zone of the forward $\mathrm{x}$ delayed line.

(lag $-1: z=3.06 ; z=6.11 ; z=3.79$ ), in addition to corners and fouls committed by the opponent (lag $-1: z=3.04$; 4.77), respectively. As for the spatial interaction, in the previous event a pattern of confrontation was noted against the last opposing defensive line through the centre (lag- 1: $z=3.42$ ) and right flank (lag $-1: z=2.01$ ), even with numerical inferiority (lag $-1: z=2.53)$. These effective offensive patterns tended to be completed in the central corridor, zone 8 (lag 0: $z=4.99$ ) and 11 (lag $0: z=7.06)$ and facing the opponent's last line of defenders (lag 0: $z=4.65 ; 5.06$ ), indicating a relationship with the space.

(II) Against opponents of intermediate quality, the beginning of the offensive sequence from intervention of the team's goalkeeper was identified as a pattern (lag -2: $z=2.44$ ). When in a state of transition, the team tended to perform ball conduction (lag $-4: z=2.85$ ) to approach the shot moment. A greater presence of actions in possession development was noted against this opponent quality, through dribble (lag $-5: z=2.62$ ) and crossing (lag -4: $z=2.01$ ), or dribble (lag -3: $z=2.51$ ) followed by a foul suffered (lag $-2: z=2.16$ ) and a shooting attempt (lag $-1: z=2.27$ ), which were identified in conduct prior to the final shot. The numerical interaction in the centre of the game tended to be inferior, however, with constant spatial positioning of the players on the most offensive line, with the ball, inside and along the flank, against the last line of opponent defenders (lag -2; $-1: z=2.21 ; 2.72)$. The shot itself tended to occur in the central path, in the central offensive mid-zone (8) (lag $0: z=2.84)$ and central offensive (11) (lag 0: $z=3.63$ ).

(III) Against low quality opponents, the team tended to initiate the offensive sequences by disarming (lag $-3: z=2.93)$ in the attack field, followed by ball conduction when in transition (lag $-2: z=2.64$ ). More actions were identified in the development of possession of the ball, indicating that, in this situation, the team valued first to leave the state of transition and then to move forward. Several actions based on fouls suffered (lag -3: $z=3.44$ ) and corners provided by the opponent (lag -1: $z=1.97$ ) were identified in the events prior to the shots. When the team did not reach the end through set-pieces, they took advantage of crossings executed mainly by the right corridor (9; lag -2 : $z=2.02$ ), aerial duels (lag $-1: z=2.12$ ), or dribble (lag $-1: z=1.97$ ), aiming to infiltrate the opponent's area to finalize. In this context, superiority (lag $-1: z=2.18$ ), face to face with the last defensive line (lag $-1: z=2.05$ ) or with the opposing goalkeeper (lag -1: $z=3.48$ ), was identified as a pattern in the event exactly before the outcome, which tended to occur in the central offensive zone (11) (lag $0: z=3.79)$, with numerical superiority ( $\operatorname{lag} 0: z=2.09$ ) when facing the last opponent line (lag 0: $z=3.15$ ).

\section{Patterns in offensive sequences with effectiveness} and outcome in goal (Fgl)

Figure 4 shows the offensive patterns detected in goal situations (Fgl) against opponents of high quality (IV), intermediate quality (V), and low quality (VI).

(IV) The pattern with maximum effectiveness (Fgl) found against high quality opponents pointed to an offensive construction that heavily used the right side corridor, zones 9 and 12 (lag $-5 ;-4: z=3.72 ; 3.11)$, mainly attacking the outer part of the last opponent line (lag $3: z=1.97)$, in order to approach and infiltrate the large opponent area, either through victories in aerial duels (lag -4: $z=4.46$ ) or ball conduction (lag -2: $z=6.04$ ) and dribble (lag $-1: z=1.96)$. The goal tended to occur in 


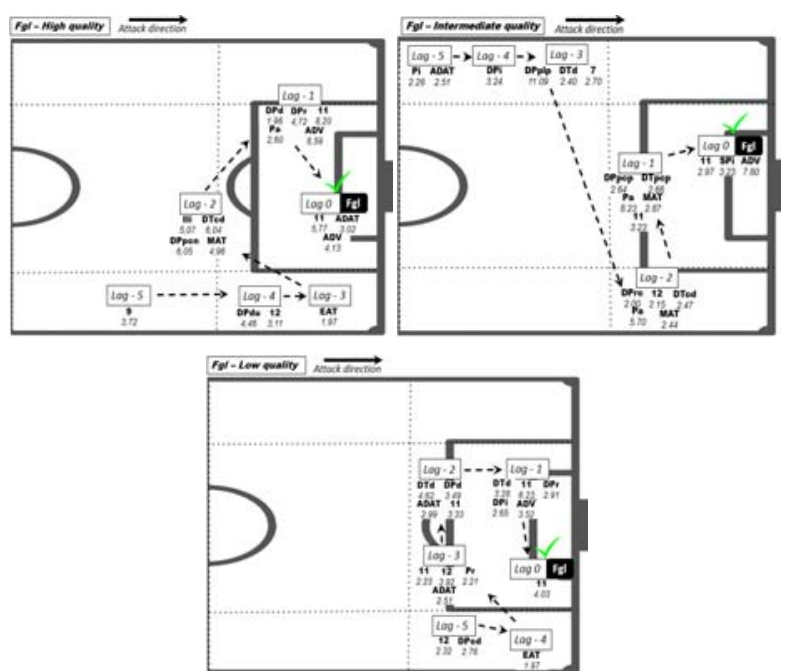

Figure 4. Offensive patterns referring to the achievement of goals against opponents of high (IV), intermediate (V), and low quality (VI).

Note: Ili: Infringement of the opponent to the laws of the game; DTcd: Ball conduction; DTd: Dribble; DTpcp: Short positive pass; DPczp: Positive crossing; DPdu: Duel; DPplp: Long pass positive; DPpcn: Short negative pass; DPd: Dribble; DPr: Shot; DPi: Opponent's violation of the laws of the game; DPpcp: Short positive pass; DPrc: Ball control; DPcd: Ball conduction; 9 ; Zone nine; 12: Zone twelve; 11: Zone eleven; 7: Zone seven; Pa: Absolute inferiority; Pi: Equality pressed; SPi: Equality not pressed; Pr: Relative inferiority; EAT: Outer zone of the forward line versus the forward line; ADV: Line ahead versus goalkeeper of the opposing team; ADAT: Early line versus delayed line; MAT: Midline x delayed line; Fgl: goal.

dribble (lag -1: $z=1.96$ ). The goal tended to occur in the central offensive zone (lag 0: $z=5.77$ ), facing the last opponent line or on its back (lag 0).

(V) Against opponents of intermediate quality, the team presented a mixture between predominantly collective actions, such as combinations between short passes, long passes and ball control, with individual dribble and ball handling actions. A possible inversion of the game, through a long pass (lag -3: $z=11.09$ ) from the left corridor (7) (lag -3: $z=2.70$ ), received in the right corridor (12) (lag $-2: z=2.15)$, followed by infiltration in the central offensive zone (lag $-1: z=3.23$ ), preceded the outcome in goal, which tended to occur in numerical equality (lag 0: $z=3.23$ ) and in the empty zone between the last defensive line and the opposing goalkeeper (lag 0: $z=7.80$ ).

(VI) Against low quality opponents, it was identified that the team tended to explore the right path (12) (lag $-5: z=2.32$ ) through ball conduction (lag $-5: z=2.76$ ), mainly in situations of confrontation against the outer zone of the last opponent line (lag $-4: z=1.97$ ), in order to infiltrate the central offensive zone and overcome the last defensive line (lag $-2: z=2.99)$ by dribble (lag $2: z=4.62 ; 3.49)$. After overcoming the last scoring line, attempts at submissions that rebounded (lag $-1: z=2.91$ ) and infractions committed by the opponent within the area (lag $-1: z=2.65)$, were patterns that preceded and activated the goal end in the central offensive zone (lag $0: z=4.03)$.
Patterns in offensive sequences without effectiveness (Fbad, Fgrad, Ff and Fi)

Figure 5 shows the map of interactions between ineffective offensive patterns detected against opponents of high quality (VII), intermediate quality (VIII) and low quality (IV).

(VII) Against high quality teams, it was identified that the negative outcome tended to occur in the intermediate sector, zones 4 (lag 0: $z=3.19$ ), 5 (lag 0: $z=3.48), 6(\operatorname{lag} 0: z=2.94), 7(\operatorname{lag} 0: z=3.12)$, and $9(\operatorname{lag}$ $0: z=4.15)$, especially when in situations of pressure in numerical equality (lag $0: z=3.41$ ) and with the ball being worked in the defensive field by the players from the back line (lag $0: z=2.80)$ and the second construction line (lag $0: z=2.30)$. Ball control actions (lag $-1: z=4.33)$, and side throws (lag $-1: z=2.06)$, which also occurred in the defensive half of the field, in situations of pressure in the centre of the game (lag $-1: z=3.01)$.
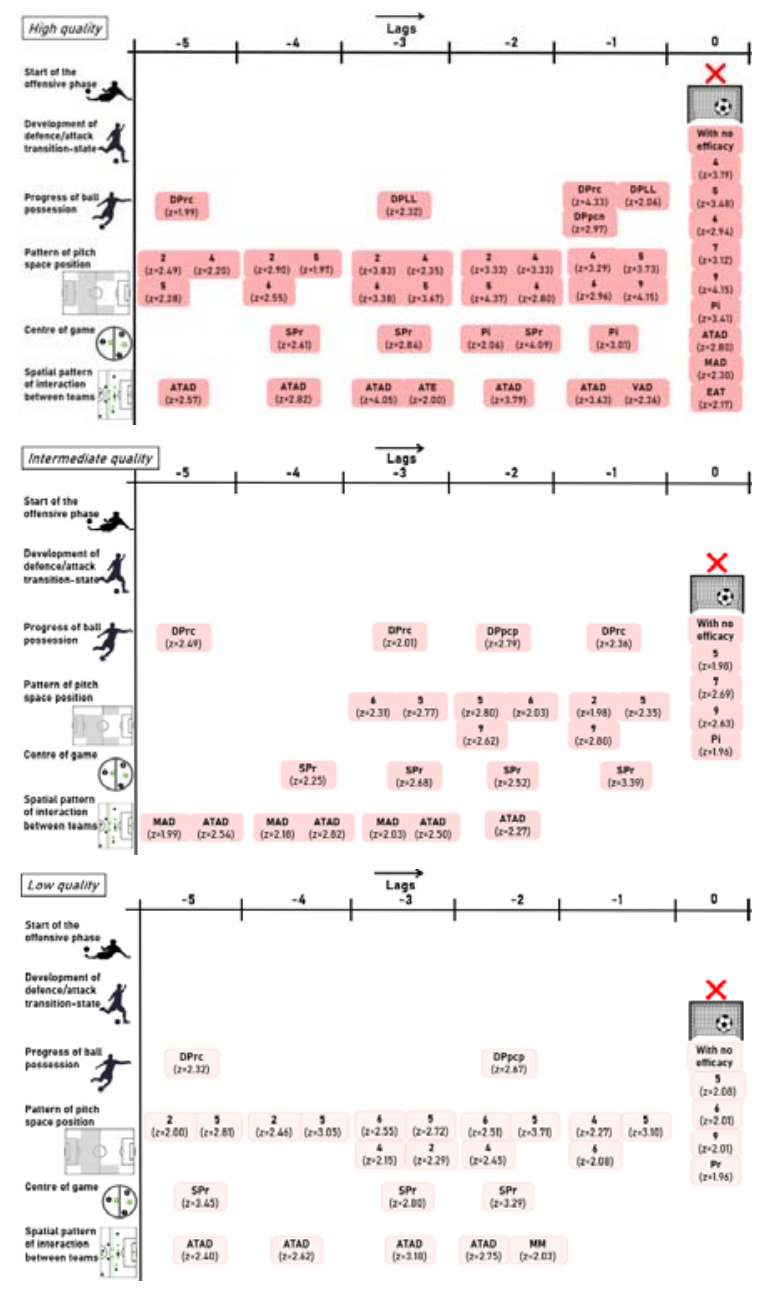

Figure 5. Map of interactions between offensive patterns without effectiveness against opponents of high (VII), intermediate (VIII), and low quality (IX).

Note: DPLL: Throw-in; DPpcn: Negative short passing; DPrc: Ball control; DPpcp: Positive short passing; Pr: Relative numerical inferiority; Pi: Pressure in numerical equality; SPr: short passing; Pr: Relative numerical inferiority; Pi: Pressure in numerical equality; SPr:
Relative numerical superiority; ATAD: Back line versus offensive line; MAD: Mid line versus offensive line; MM: Mid line versus mid line. 
combination of short passes (lag $-2: z=2.79)$ and ball control (lag $-3 ;-1: z=2.36 ; 2.01)$ in the defensive and defensive intermediary (lag $-3 ;-2 ;-1)$, even in numerical superiority in the centre of the game (lag $-3 ;-2 ;-1$ : $z=2.68 ; 2.52 ; 3.39$ ), were patterns of actions that preceded and activated the negative outcome. It is noteworthy that these actions were carried out at the moment of developing possession of the ball, when the state of transition had already been overcome. The negative outcome itself tended to run in the Middlefield zone (lag 0: $z=1.98 ; 2.69 ; 2.63$ ) mainly when pressed and in numerical equality at the centre of the game (lag $0: z=1.96)$.

(IV) Against low quality teams, the ineffective outcome tended to occur in zones 5 and $6(z=2.08$; $2.01)$ and right offensive midfielder $(z=2.01)$, with numerical inferiority in the centre of the game $(z=1.96)$. In events prior to the ineffective outcome, the ball possession was maintained in the defensive half of the field (zones 2, 4, 5 and 6) and was carried out especially by the players on the first building line $(z=2.40 ; 2.62$; $3.18 ; 2.75)$, these being actions that activated the negative outcome.

\section{Discussion}

The present study aimed to investigate the influence of the opponent's quality on offensive efficacy of a Brazilian youth football team. As found in other studies with young players in a competitive situation (Caballero, García-Rubio \& Ibáñez, 2017), the quality of the opponent has a considerable effect on the performance of tactical actions and offensive construction.

About this, we report that in effective offensive sequences, the team presented different patterns to start the offensive phase against opponents of different levels; through interception actions or through the conquest of side throws - against high quality opponents - through actions of defensive intervention by the goalkeeper against intermediate quality opponents - and, after disarming - against low quality opponents -. Despite these differences in relation to specific actions, there was a tendency to start the offensive phase from direct ball recoveries and in the proximity of the outcome event (shot). In sequences that ended in a goal, the only pattern that started the offensive phase in the final events of the sequence was identified against high quality teams and was indirect.

Regarding ball recovery actions, the literature points out that qualified teams usually employ proactive defensive strategies, in order to recover the ball directly from opponents through interceptions, tackles, defensive actions followed by pass and defensive goalkeeper intervention (Barreira et al., 2014); the most effective occurring as soon as possible after losing ball possession (Vogelbein, Nopp \& Hökelmann, 2014; Casal-Sanjurjo, Andujar, Ardá, Maneiro, Rial \& Losada, 2020) and in the central corridor (Barreira et al., 2014). Casal-Sanjurjo et al. (2020), pointed out that the effectiveness ball possession recoveries of male teams that participated in the 2014 World Cup was associated with time and space variables, being more successful when they occurred after the loss of possession in the offensive field and after a short/medium time defensive transition. In addition, the chances of recovering the ball increase the further the team is from its own goal, principally in the Midfield zone - defensive and offensivehaving the highest percentage of recovery of the ball (Casal-Sanjurjo et al., 2020).

Fernandez-Navarro, Ruiz-Ruiz, Zubillaga \& Fradua (2020), with Spanish teams, already brings us a relationship of the recovery of the ball possession with the quality of the opponent, where pointed out that the higher the quality of the opponent, lower the chance of recovering ball possession in advanced areas of the field. Possibly, due to the good ability of these teams to climb the marking lines, maintain good compaction and avoid inter-line play.

After regaining ball possession, a greater presence of tactical action patterns was noted at the time of possession development, that is, after leave the transition (Figures 3 and 4). This indicates a tendency to build shot opportunities from an indirect perspective, prioritizing primarily to overcome an unfavourable centre of the game (as with pressure), leaving the transition and entering in a possession development. About this, high quality German teams opted for an offensive construction style, preferably indirect, and aimed to take control and advance in possession development (Kempe, Vogelbein, Memmert \& Nopp, 2014).

However, this does not mean that the offensive effectiveness is observed only in sequences with a specific construction characteristic. Machado, Barreira \& Garganta (2013) reported that in national teams of the 2010 World Cup the offensive efficacy was not a reflection of a certain duration of the strings (short or long) or of playing styles (direct or indirect). Borges et al. (2019) reinforce this idea by concluding with teams of youth Brazilian and Italian football players that it is possible to be effective by opting for different styles of offensive 
construction.

Also, in this moment of development and against high quality opponents, the team presented the pattern of requesting the goalkeeper participation to build their sequences (Figure 3). Errekagorri, Castellano, Echeazarra (2020) indicates that ball possession is conditioned by the opponent quality, the higher the opponent's quality, the harder it is to maintain the ball possession. Qualified teams increasingly compact lines, close spaces for infiltration, increase density and pressure in the centre of the game (Barreira et al., 2015), which can make the team in an offensive moment prone to return on the pitch to maintain ball possession without forcing infiltrations in unfavourable situations, as well as trying to move the opponent lines with the prospect of finding possible gaps to advance during this marking offset.

Regarding advancing on the playing field, it was identified that: ball conduction was a pattern of action against all levels of opponents and in all outcomes with completion (including goal) and especially in transition (Figures 3 and 4). Dribble was present in all goal outcomes and against all three opponent's quality (Figure 4). Dribble and ball conduction are predominantly found against low quality teams (Lago-Peñas \& Martin, 2007; Taylor, Mellalieu, James \& Shearer, 2008). This is explained by the fact that teams with deficient or slow defensive coordination - which assume inferior quality - grant more space and shots to opponents (Lago-Ballesteros, Lago, Rey, Casáis \& Domínguez, 2012); it is possible that finding more free spaces, due to the low defensive coordination of the opponent, encourages the team players in the offensive phase to perform more individual actions.

Amatria, Maneiro \& Anguera (2019) highlight dribble as an important action to change the direction of the game to the side corridors, avoiding the central corridor (more congested). However, Barreira et al. (2015) when analysing World Cup games from 1982-2010, identified that spaces are getting smaller, increasing the use of passes (including long ones) and decreasing the appearance of individual actions. Nevertheless, this does not seem to be a reality in all competitive contexts, because individual actions were patterns associated in this context with youth players.

Due to this scarcity of free spaces to build the game, set-pieces are becoming increasingly important (Kubayi, 2020). World cups usually indicate trends and there is in fact an increase in the number of goals scored from setpieces in the latest editions of men's world cup (Kubayi,
2020). The results of the present study indicate that the set-pieces were standard actions in the final events of all outcomes with shot, against all quality opponents (Figure 3). However, in goal sequences, the set-pieces had a direct connection only against low quality opponents, these being mainly maximum penalties, within 11 zone (Figure 4). This corroborates studies who point out the high frequency, but low effectiveness of dead ball actions, which normally do not end in shot or goal (Maneiro et al., 2017; Fernández-Hermógenes, Camerino \& Alcaraz, 2017).

Considering all the outcomes of sequences with effectiveness, what appears in the literature and was also reinforced by our results is the importance of location and spatial configuration of interaction at the time of the shot. Shots from zone 11, with a spatial configuration of confrontation against the last opponent line or face-to-face with the opponent's goalkeeper, were always present in the sequences with effectiveness (including goal) and against the three quality opponents' (Figures 3 and 4). Teams that receive more infiltrations in their own area are significantly more likely to concede more goals (Ruiz-Ruiz et al., 2013). Studies point out that the player location at the moment of finalization totally influences the result of the action, where areas with a shorter distance and a wider angle in relation to the goal (zone 11) register greater effectiveness (Rathke, 2017; Gonzales-Rodenas et al., 2020).

Thus, the importance of being able to progress on the field of play is reinforced in order to approach the opponent's penalty box - where the goals occur -, which increases the chance of offensive effectiveness. In this regard, the findings of the present study suggest that being able to leave the first stage of construction (from your own field half) and advance, increase the tendency of an effective outcome, while being unable to advance on the field of play and maintain the ball possession on your own field half are related to negative outcomes (Figure 5). The same was observed in the study by Aguado-Méndez, González-Jurado \& Otero-Saborido (2020). The fundamental objective of the offensive transition must be to move towards advanced zones quickly and effectively, taking advantage of the momentary positional disorganization of the opponent (Garganta, Guilherme, Barreira, Brito \& Rebelo, 2013), avoiding unproductive or superfluous passes, which are predictive of worse offensive results (Collet, 2013). Thus, indicating that, regardless of whether building in rapid transition or developing possession, the important thing is to be objective and effective in causing problems for the 
opposing defensive organization.

In addition to the spatial configuration, the numerical configuration was also shown to be relevant for offensive sequences without effectiveness (Figure 5). Being in a situation of pressure in the centre of the game (numerical inferiority or pressure in numerical equality) was a pattern observed in the last event (lag 0) against all opponents' quality (Figure 5). Barreira et al. (2015) points out that over the past few decades, situations of equality and numerical inferiority are increasingly frequent, increasing the complexity of decisions taken under pressure. Thus, the chance of losing possession of the ball in a congested centre of the game becomes greater, especially when considering young players, still in process of training and refinement of decision making and execution.

The scarcity of studies with youth teams in official competitions was a limiting factor for the discussion of the data. Thus, the need for new studies, with greater coverage, that aim to contribute, in a systemic perspective, to understanding pattern actions and interaction of youth football players, is reinforced.

\section{Conclusion}

In conclusion, the findings partially confirm the initial hypotheses. Differences were found between the offensive patterns of sequences with and without efficacy, mainly in relation to numerical interaction in the centre of the game, spatial interaction, area of action, and actions taken. The opponent's quality differentiated the patterns in some aspects related to the beginning, construction and outcome of the offensive sequence. However, several behaviours were similar against all opponents' quality, demonstrating that this team had a stabilized game model. The individual actions of dribble and ball conduction have always been important actions to progress on the field, especially through the side corridors, where they managed to funnel to the main finishing zone (inside the penalty box) or managed to win set pieces. Infiltrate inside the penalty box, attack the last defensive line or the space between the goalkeeper and the opponents last line have been present in positive patterns. On the other hand, combining many passes and receptions in the first stage of construction (defensive field) without advancing quickly, caused many negative patterns, which can also indicate the positive effect that putting pressure on the opponents ball out has, especially because they are young players in process of development.
We recommend that professionals who work with youth players encourage them to: advance quickly from the defensive field to more advanced zones; stand between the lines to attack the opponent's last defensive line; perform dribble actions and ball conduction; perform unmarks rupture towards the space between the goalkeeper and the opponents last defensive line; in addition to pressing the opponent into their own field (when without the ball). In this sense, youth players must be stimulated and trained to improve the attributes related to decision making and motor skills, making them prone to choose the most appropriate techniques to solve specific problems of the game to maintain the ball possession, progress on the pitch and attack the opposing goal minimizing the effects of aspects such as the characteristic and opponent quality.

\section{Acknowledgments}

We would like to thank the Coordination of Improvement of Higher Education Personnel (CAPES/ Brazil) and the National Council of Technological and Scientific Development (CNPq).

\section{References}

Aguado-Méndez, R., González-Jurado, J. A. \& OteroSaborido (2020). Observational analysis of goals conceded by Real Betis in La Liga: case study. Retos, (38), 355362.

Amatria, M., Maneiro, R., \& Anguera, M.T. (2019).Analysis of Successful Offensive Play Patterns by the Spanish Soccer Team. Journal of Human Kinetics, 69, 191200. https://doi.org/10.2478/hukin 20190011

Anguera, M.T., Blanco-Villaseñor, A., Hernández-Mendo, A., \& Losada, J.L. (2011). Diseños observacionales: ajuste y aplicación en psicología del deporte. Cuadernos de Psicología del Deporte, 11(2), 63-76.

Anguera, M. T., Camerino, O., Castañer, M., SánchezAlgarra,P., \& Onwuegzbuzie,A.J. (2017).The specificity of observational studies in physical activity and sports sciences: Moving forward in mixed methods research and proposals for achieving quantitative and qualitative symmetry. Frontiers in Psychology, 8, 2196. https:// doi.org/10.3389/fpsyg.2017.02196

Bakeman, R., \& Quera, V. (2011). Sequential analysis and observational methods for the behavioral sciences. Cambridge: Cambridge University Press.

Barreira, D., Garganta, J., Castellano, J., Machado, J., \& Anguera, M.T. (2015). How elite-level soccer dynamics 
has evolved over the last three decades? Input from generalizability theory. Cuadernos de Psicología del Deporte, 15(1), 51-62. https://doi.org/10.4321/S157884232015000100005

Barreira, D., Garganta, J., Guimarães, P., Machado, J. C., \& Anguera, M. T. (2014). Ball recovery patterns as a performance indicator in elite soccer. Journal of Sports Engineering and Technology, 228(1), 61-72.https://doi.org/ $10.1177 / 1754337113493083$

Barreira, D., Garganta, J., Prudente, J., \& Anguera, M. T. (2012). Desenvolvimento e validação de um sistema de observação aplicado à fase ofensiva em Futebol: SoccerEye. Revista Portuguesa de Ciências do Desporto, 12(3), 32-57.

Borges, P. H., Garganta, J., Guilherme, J., Jaime, M. O., Menegassi, V. M., Rechenchosky, L., ... \& Rinaldi, W. (2019). Tactical efficacy and offensive game processes adopted by Italian and Brazilian youth soccer players. Motriz, 25(2), e101922.https://doi.org/10.1590/s19806574201900020017

Caballero, P., García-Rubio, J., \& Ibáñez, S.J. (2017). Influence of situational variables on the U' 18 soccer performance analysis. Retos, 32, 224-227. https://doi.org/ 10.47197/retos.v0i32.56071

Casal-Sanjurjo, C.,Andujar, M., Ardá, A., Maneiro, R., Rial, A., \& Losada, J. (2020). Multivariate analysis of defensive phase in football: Identification of successful behavior patterns of 2014 Brazil FIFA World Cup. Journal of Human Sport and Exercise, 0, in press. https://doi.org/10.14198/ jhse.2021.163.03

Castelão, D. P., Garganta, J., Afonso, J., \& Teoldo, I. (2015). Análise sequencial de comportamentos ofensivos desempenhados por seleções nacionais de futebol de alto rendimento. Revista Brasileira de Ciência do Esporte, 37(3), 230-236.https://doi.org/10.1016/j.rbce.2015.05.001.

Castellano, J., Álvarez, D., Figueira, B., Coutinho, D., \& Sampaio, J. (2013). Identifying the effects from the quality of opposition in a Football team positioning strategy. International Journal of Performance Analysis in Sport, 13(3), 822-832. https://doi.org/10.1080/ 24748668.2013.11868691

Chaverra, B., Gaviria, D. \& González, E. (2019). El estudio de caso como alternativa metodológica en la investigación en educación física, deporte y actividad física. Conceptualización y aplicación. Retos, 35, 422-427.

Cohen, J. (1960). A coefficient of agreement for nominal scales. Educational and Psychological Measurement, 20(1), 37-46. https://doi.org/10.1177/001316446002000104.

Collet, C. (2013). The possession game? A comparative analysis of ball retention and team success in European and international football 2007-2010. Journal of Sports Sciences, 31(2), 123-136. https://doi.org/10.1080/ 02640414.2012.727455

Costa, J. C., Garganta, J., Fonseca,A., \& Botelho, M. (2002). Inteligência e conhecimento específico em jovens futebolistas de diferentes níveis competitivos. Revista Portuguesa de Ciências do Desporto, 2(4), 7-20. https:// doi.org/10.5628/rpcd.02.04.07

Duarte, R., Araújo, D., Folgado, H., Esteves, P., Marques, P., \& Davids, K. (2013). Capturing complex, non-linear team behaviours during competitive football performance. Journal of Systems Science and Complexity, 26(1), 62-72. https://doi.org/10.1007/s11424-013-2290-3

Fernández-Hermógenes, D., Camerino, O., \& Alcaraz, A. G. (2017) Set-piece offensive plays in soccer. Apuntamentos Educacion Fisicay Deportes, 129(3), 78-94. https://doi.org/ 10.5672/apunts.2014-0983.es.(2017/3).129.06

Fernandez-Navarro, J., Ruiz-Ruiz, C., Zubillaga, A., \& Fradua, L. (2020). Tactical Variables Related to Gaining the Ball in Advanced Zones of the Soccer Pitch: Analysis of Differences Among Elite Teams and the Effect of Contextual Variables. Frontiers in Psychology, 10(3040). https://doi.org/10.3389/fpsyg.2019.03040

Folgado, H., Bravo, J., Pereira, P., \& Sampaio, J. (2018). Towards the use of multidimensional performance indicators in football small-sided games: the effects of pitch orientation. Journal of Sports Sciences, 37(9), 1-8. https://doi.org/10.1080/02640414.2018.1543834

Garganta, J., Guilherme, J., Barreira, D., Brito, J., \& Rebelo, A. (2013). Fundamentos e Praticas para o Ensino e Treino do Futebol. In F. Tavares (Ed.), Jogos Desportivos Coletivos: Ensinar a jogar (pp.199-263). Porto: Editora da Faculdade de Desporto da Universidade do Porto.

Gómez, M. A., Mitrotasios, M., Armatas, V., \& Lago-Peñas, C. (2018). Analysis of playing styles according to team quality and match location in Greek professional soccer. International Journal of Performance Analysis in Sport, 18(6), 986-997. https://doi.org/10.1080/ 24748668.2018.1539382

Gonçalves, E., Noce, F., Barbosa, M. A., Figueiredo, A. J., Hackfort, D., \& Teoldo, I. (2017). Correlation of the peripheral perception with the maturation and the effect of the peripheral perception on the tactical behaviour of soccer players. International Journal of Sport and Exercise Psychology, 18(5), 687-699. https://doi.org/10.1080/ 1612197X.2017.1329222

Gonzalez-Rodenas, J., Mitrotasios, M., Aranda, R., \& Armatas,V.(2020). Combined effects of tactical, technical and contextual factors on shooting effectiveness in European professional soccer. International Journal of Per- 
formance Analysis in Sport, 20(2), 280-293. https: / / doi.org/10.1080/24748668.2020.1743163

Gréhaigne, J. F., \& Godbout, P. (1995). Tactical Knowledge in Team Sports From a Constructivist and Cognitivist Perspective. Quest, 47(4), 490-505. https: / /doi.org/ 10.1080/00336297.1995.10484171

Hewitt, A., Greenham, G., \& Norton, K. (2016). Game style in soccer: what is it and can we quantify it? International Journal of Performance Analysis in Sport, 16(1), 355-372. https: / / doi.org/10.1080/ 24748668.2016.11868892

Kempe, M., Vogelbein, M., Memmert, D., \& Nopp, S. (2014). Possession vs. Direct Play: Evaluating Tactical Behavior in Elite Soccer. International Journal of Sports Science, 4(6A), 35-41. https://doi.org/10.5923/ s.sports. 201401.05

Kubayi, A. (2020). Analysis of Goal Scoring Patterns in the 2018 FIFAWorld Cup. Journal of Human Kinetics, 71, 205 210. https: / /doi.org/10.2478/hukin-2019-0084

Lago-Ballesteros, J., Lago, C., Rey, E., Casáis, L., \& Domínguez, E. (2012). El éxito ofensivo en el fútbol de elite - Influencia de los modelos tácticos empleados y de las variables situacionales. European Journal of Human Movement, 28, 145-170.

Lago-Peñas, C., \& Martin, R. (2007) Determinants of possession of the ball in soccer. Journal of Sports Sciences, 25(9), 969-974. https://doi.org/10.1080/ 02640410600944626

Machado, J. C., Barreira, D., \& Garganta, J. (2014). The influence of match status on attacking patterns of play in elite soccer teams. Revista Brasileira de Cineantropometria e Desempenho Humano, 16(5), 545-554. https://doi.org/ 10.5007/1980-0037.2014v16n5p545

Machado, J. C., Barreira, D., \& Garganta, J. (2013). Eficácia ofensiva e variabilidade de padrões de jogo em futebol. Revista Brasileira de Educação Física e Esporte, 27(4), 667677. https: / / doi.org/10.1590/S180755092013000400014

Maneiro, R.,Ardá,T., Rial,A., Losada, J. L., Casal, C.A., \& López-García. (2017). Análisis descriptivo y comparativo de los saques de esquina - UEFA Euro 2012. Revista Andaluza de Medicina del Deporte, 10(3), 95-99.https: / / doi.org/10.1016/j.ramd.2016.06.013

Pic, M., \& Castellano, J. (2017). Influence of match location in the spanish Copa del Rey. Retos, 31, 202-206. https: / /doi.org/10.47197/retos.v0i31.51366

Praça, G. M., Lima, B. B., Bredt, S. G., Sousa, R. B., Clemente, F. M., \& Andrade, A. G. (2019). Influence of match status on players' prominence and teams' network properties during 2018 FIFA World Cup. Frontiers in
Psychology, 10(695). https: / / doi.org/10.3389/ fpsyg.2019.00695

Praça, G. M., Silva, M. V., Barreira, D., Garganta, J., \& Greco, P. (2017). Em busca de padrões de jogo da fase ofensiva em pequenos jogos de futebol. Conexões: Educação Física, Esporte e Saúde, 15(1), 1-11. https://doi.org/ 10.20396/conex.v15i1.8646428

Rathke, A. (2017). An examination of expected goals and shot efficiency in soccer. Journal of Human Sport and Exercise, 12(2proc), 514-529. https: / / doi.org/10.14198/ jhse.2017.12.Proc2.05

Ruiz-Ruiz, C., Fradua, L., Fernández-García,A., \& Zubillaga, A. (2013). Analysis of entries into the penalty area as a performance indicator in soccer. European Journal of Sport Science, 13(3), 241-248. https: / /doi.org/10.1080/ 17461391.2011 .606834

Sarmento, H. (2012). Análise do jogo de futebol - Padrões de jogo ofensivo em equipas de alto rendimento: uma abordagem qualitativa. (Doctoral thesis, University of Trás-os-Montes e Alto Douro, Vila Real, Portugal).

Tabachnick, B. G., \& Fidell, L. S. (2012). Using multivariate statistics. 6thed. London: Pearson Education.

Taylor, J. B., Mellalieu, S. D., James, N., \& Shearer, D. (2008). The influence of match location, quality of opposition, and match status on technical performance in professional association football. Journal of Sports Sciences, 26(9), 885-895. https://doi.org/10.1080/ 02640410701836887

Vogelbein, M., Nopp, S., \& Hökelmann,A. (2014). Defensive transition in soccer - are prompt possession regains a measure of success? A quantitative analysis of German Fußball-Bundesliga 2010/2011. Journal of Sports Sciences, 32(11), 1076-1083.https://doi.org/10.1080/ 02640414.2013 .879671

Williams, A. M., Davids, K., \&Williams, J. G. (2000). Visual perception and action in sport. $2 \mathrm{ed}$. London: E \& FN Spon.

Wilson, M. R., Wood, G., \& Vine, S. J. (2009). Anxiety, Attentional Control, and Performance Impairment in Penalty Kicks. Journal of Sport \& Exercise Psychology, 31(6), 761-775.https://doi.org/10.1123/jsep.31.6.761 